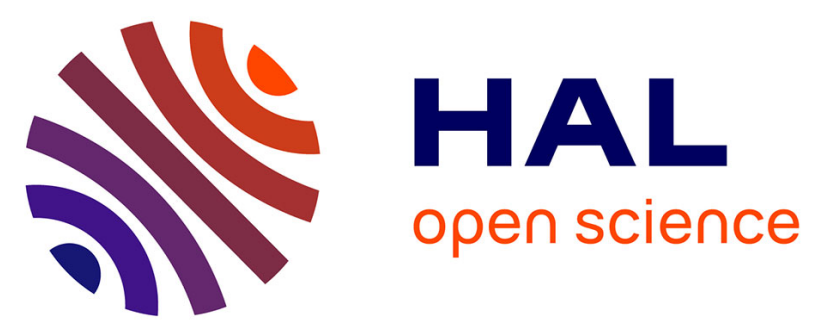

\title{
SARMENTI: in-situ real-time soil nutrients and gaseous emission measurement
}

Suzanne Lesecq, M. Gougis, E. Gouze, A. Di Matteo, E. Alessi, V Di Palma, S. Di Salvo, A. O'Riordan, H. Shao, G. Mouzakitis, et al.

\section{To cite this version:}

Suzanne Lesecq, M. Gougis, E. Gouze, A. Di Matteo, E. Alessi, et al.. SARMENTI: in-situ real-time soil nutrients and gaseous emission measurement. 2020 7th International Conference on Energy Efficiency and Agricultural Engineering (EE\&AE), Nov 2020, Ruse, Bulgaria. pp.1-4, 10.1109/EEAE49144.2020.9278984 * cea-03155780

\section{HAL Id: cea-03155780 https://hal-cea.archives-ouvertes.fr/cea-03155780}

Submitted on 2 Mar 2021

HAL is a multi-disciplinary open access archive for the deposit and dissemination of scientific research documents, whether they are published or not. The documents may come from teaching and research institutions in France or abroad, or from public or private research centers.
L'archive ouverte pluridisciplinaire HAL, est destinée au dépôt et à la diffusion de documents scientifiques de niveau recherche, publiés ou non, émanant des établissements d'enseignement et de recherche français ou étrangers, des laboratoires publics ou privés. 


\section{SARMENTI: in-situ real-time soil nutrients and gaseous emission measurement}

\author{
S. Lesecq, M. Gougis, E. \\ Gouze \\ Université Grenoble Alpes, \\ CEA-LIST \\ Grenoble, France \\ suzanne.lesecq@cea.fr \\ G. Dudnik, M. Correvon \\ CSEM SA \\ Neuchâtel, Switzerland \\ gabriela.dudnik@csem.ch
}

\author{
A. di Matteo, V. Di Palma, \\ E. Alessi, S. di Salvo \\ STMicroelectronics S.1.r. \\ Naples, Italy \\ andrea.di-matteo@st.com
}

K. Daly, B. Molleman

Teagasc,

Carlow, Ireland

Karen.Daly@teagasc.ie

\author{
A. O'Riordan, H. Shao, G. \\ Mouzakitis \\ Tyndall National Institute \\ Cork, Ireland \\ alan.oriordan@tyndall.ie \\ T. C. Balan, C. Dimitru

$$
\text { ATOS }
$$ \\ Brasov, Romania \\ catalin.dumitru@atos.net
}

\section{G. Ponsardin}

Terrasolis

Châlons-en-Champagne,

France

gael.ponsardin@marne.chamb agri.fr

\author{
G. Mailat
}

Spiro

Brasov, Romania

george.mailat@spiroagri.ro

\begin{abstract}
This paper presents the vision of the $\mathrm{H} 2020 \mathrm{EU}$ project SARMENTI whose objective is to develop an IoT device that monitors in real-time and in situ nutrients in the soil and gaseous emissions just above the soil, and provide advices to the farmer regarding appropriate fertilization strategies. The development methodology is presented here, the measurement requirements being established with end-users. Then the device architecture is summarized.
\end{abstract}

Keywords-agriculture 4.0, soil nutrients, gaseous emission, in situ monitoring, sensors

\section{INTRODUCTION}

The food supply chain is a key strategic sector in Europe from economical ( $6 \%$ of Europe's GVA), labor (jobs for 24 million people) and cultural perspectives [1]. In parallel, demand for sustainably produced food is driving current strategies for intensification of the agricultural sector worldwide. Agriculture sustainable intensification will test the AgriFood sector resilience against increased cost of inputs, price fluctuations, declining water quality and climate change. To meet these challenges farmers need to adopt a whole-farm approach to resource efficiency for increased productivity, centered on the greater application of knowledge per hectare. Resource Management is central to meeting these challenges, soil being an important natural resource on the farm [2], essential for food production and security. Soil quality and fertility across the farm is assessed by soil testing typically once every 5 years, every $2-4$ ha, to measure nutrient status, drainage characteristics, and compaction and used to inform farmers on more efficient fertilizer and lime use, grazing management and land use.

Among the unsustainability factors, the overuse of chemical fertilizers in agriculture has a negative environmental impact, specifically, losses of nitrogen $(\mathrm{N})$ and phosphorous (P) to the aquatic environment [3] and an estimated $18 \%$ of land is affected by $\mathrm{N}$ and $\mathrm{P}$ contamination [4]. However, these compounds, either provided by organic or chemical fertilizers, are needed to replace nutrients removed during farming (crops, grass) and to increase productivity. Moreover, agricultural soils are a major source of Greenhouse Gas (GHG) emissions, namely, nitrous oxide
$\left(\mathrm{N}_{2} \mathrm{O}\right)$ and ammonia $\left(\mathrm{NH}_{3}\right)$, due the application of nitrogenbased fertilisers and animal manures. These gases enter the earth's atmosphere causing heat to be retained instead of radiated out, thus contributing to climate change. Nitrous Oxide and methane $\left(\mathrm{CH}_{4}\right.$, also released by the soil $)$ have a global warming potential 310 and 21 times higher than $\mathrm{CO}_{2}$, respectively [5] while Ammonia has also an adverse impact on human health. There is therefore a need for greater efficiency and sustainability to make the bio-economy viable [6].

Innovative technologies for smart agriculture play an increasing role in monitoring farming conditions. These technologies will definitively make a positive change by enhancing the effectiveness of fertilisation while minimising the environmental impact.

The objective of the SARMENTI H2020 EU project is to develop a device connected to the IoT (see Fig.1), this IoT node helping the farmer to monitor in real-time and in situ soil nutrients $(\mathrm{N}, \mathrm{P}, \mathrm{K})$ that have a direct impact on plant growth, on agricultural production and on the farmer's income. The system developed will also monitor environment parameters, i.e. temperature and humidity, and gaseous emissions $\left(\mathrm{N}_{2} \mathrm{O}, \mathrm{NH}_{3}, \mathrm{CH}_{4}\right)$ also from fertilised soils arising from microbial interactions between added fertilisers, manures and soil organic matter. Data will be sent to the cloud for further analyses to provide fertilizer application advices to the farmer.

The present paper summarizes SARMENTI ambition. Then, section III describes the methodology followed by the SARMENTI consortium to develop the IoT node that will be tested in growth chambers in mid 2020 and in open-fields in 2021. The node architecture is presented in section IV. Note that the different sensors embedded in the node are currently under development. Therefore, results on their performances are not provided here. Section $\mathrm{V}$ draws future work directions.

\section{SARMENTI SYSTEM AMBITION}

Today soil analyses are neither real-time nor in-situ, thus reducing the value of the soil test results back to the farmer. 


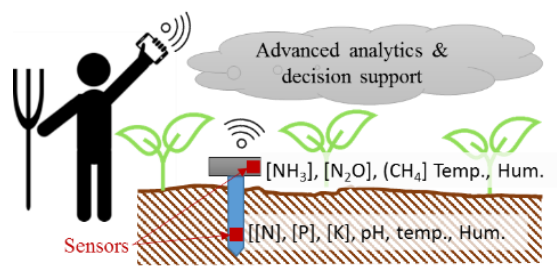

Fig. 1. SARMENTI objective

SARMENTI nutrient sensors will measure in-situ, high temporal resolution soil nutrient concentration that a farmer or advisor will interpret to implement fertiliser management strategies. SARMENTI primary use-case focuses on soil nutrient measurement for major nutrients $(\mathrm{N}$ and $\mathrm{P})$ that can be calibrated with conventional extractive methods and translated into meaningful agronomic measures of plant available nutrients required by the crop.

Nitrogen is crucial to life on earth, and the nitrogen cycle is one of the most important nutrient cycles for natural ecosystems (cf. Fig. 2). Unfortunately, farming activities can disturb the equilibrium of this cycle: excessive application of fertilisers causes water pollution, eutrophication, acidification and greenhouse gas effects due to gaseous emissions, in particular, $\mathrm{NH}_{3}, \mathrm{~N}_{2} \mathrm{O}$ and $\mathrm{CH}_{4}$ that are greenhouse gases with higher warming potential than $\mathrm{CO}_{2}$. Note that $\mathrm{CH}_{4}$ released by the soil is generated by the decomposition of manure under anaerobic conditions. Nitrogen from inorganic fertilisers, animal waste, sewage sludge applications, biological $\mathrm{N}$-fixation and crop residues can be converted to nitrous oxide in the soil [7]. By monitoring the emission of $\mathrm{NH}_{3}, \mathrm{~N}_{2} \mathrm{O}$ and $\mathrm{CH}_{4}$, SARMENTI's end-users will monitor the nitrogen cycle to avoid losses via denitrification, and the proper decomposition of manure.

As the IoT Security Foundation states, "Security is a critical element of IoT deployment, yet it is too often neglected in the development of systems" [8]. The European Union Agency for Network and Information Security highlights several threats in the "Baseline Security Recommendations for IoT, in the context of Critical Information Infrastructures" [9]. The ones with impact in agriculture sensing IoT systems are:

i. nefarious activity/abuse on IoT devices, e.g., malware, exploit kits, modification of information;

ii. eavesdropping/interception/hijacking on the interconnection network;

iii. outages and failures/malfunction, e.g., failure of devices, software vulnerabilities.

SARMENTI addresses cyber-security right from the start of

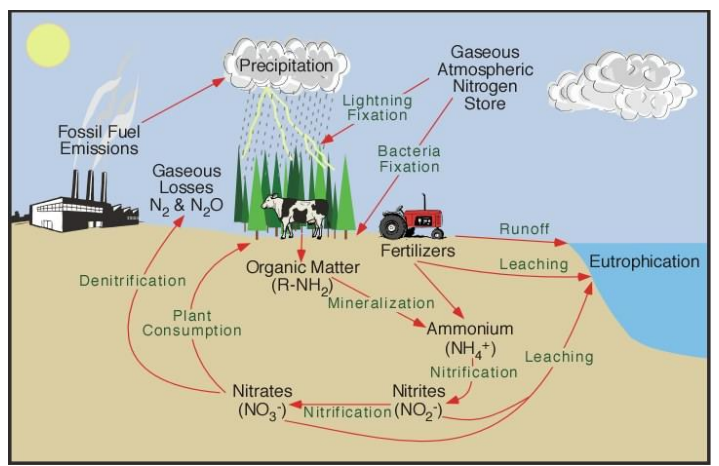

Fig. 2. Nitrogen cycle [10] the project, taking into account the application and use-case requirements in terms functionality, cost, power, and of relevant threats and vulnerabilities that should be protected against. Instead of stacking-up countermeasures in the design, we will detect attacks and raise alarms, which is in line with the general trend of including detection and reaction as cyber-security protections.

\section{SARMENTI METHODOLOGY}

End-users are part of the SARMENTI consortium to guarantee that the SARMENTI device truly answers their needs. They are located in Ireland, France and Romania, with different soil types, farm system and crop type, see Table I. As can be seen, each end-user partner offers at least one testing situation with different soil types.

TABLE I. TEST SITES

\begin{tabular}{|c|c|c|c|}
\hline Location & $\begin{array}{l}\text { Farm system/ } \\
\text { Crop type }\end{array}$ & $\begin{array}{c}\text { Soil } \\
\text { type(s) }\end{array}$ & $\begin{array}{c}\text { Current agronomic } \\
\text { management }\end{array}$ \\
\hline $\begin{array}{l}\text { Ireland } \\
\text { (Teagasc) }\end{array}$ & $\begin{array}{c}\text { Permanent } \\
\text { grassland } \\
\text { under grazing } \\
\text { (beef) }\end{array}$ & $\begin{array}{l}\text { Well \& } \\
\text { poorly } \\
\text { drained } \\
\text { mineral }\end{array}$ & $\begin{array}{l}\text { Long term P trial with } 0,15 \text {, } \\
30 \mathrm{~kg} \text { of P per ha since } 1968 \text {. } \\
\text { Representing low, optimum, } \\
\text { high nutrient status (P). } \\
\text { Grazed at } 2 \text { livestock units per } \\
\text { ha with beef cattle. Soil } \\
\text { laboratory facilities available } \\
\text { for conventional analysis of } \\
\text { extractable nutrients. }\end{array}$ \\
\hline $\begin{array}{l}\text { Ireland } \\
\text { (Teagasc) }\end{array}$ & $\begin{array}{l}\text { Permanent } \\
\text { grassland plots }\end{array}$ & $\begin{array}{c}\text { Well } \\
\text { drained } \\
\text { mineral }\end{array}$ & $\begin{array}{l}\text { Replicated small plots under } \\
\text { varying } \mathrm{N} \text { management, } \\
\text { continuous monitoring of } \\
\text { gaseous emissions ongoing } \\
\left(\mathrm{N}_{2} \mathrm{O}, \mathrm{CH}_{4} \text { and } \mathrm{CO}_{2}\right)\end{array}$ \\
\hline $\begin{array}{l}\text { Romania } \\
\text { (SPIRO) }\end{array}$ & Corn feed & $\begin{array}{l}3 \text { soil } \\
\text { types: } \\
\text { loam, clay } \\
\text { and humic } \\
\text { (peaty). }\end{array}$ & $\begin{array}{l}40 \mathrm{~T} \text { animal manure applied } \\
\text { on autumn before ploughing } \\
\text { with chemical fertiliser during } \\
\text { growing season. }\end{array}$ \\
\hline $\begin{array}{c}\text { France } \\
\text { (Terrasolis) }\end{array}$ & $\begin{array}{c}8 \text { years crop } \\
\text { rotation with } \\
\text { wheat }\end{array}$ & $\begin{array}{l}\text { Rendzine } \\
\text { on chalk }\end{array}$ & $\begin{array}{l}\text { Nitrogen fertilizer applied, } \\
\text { biomass exported. Currently } \\
\text { monitoring soil nitrogen } \\
\text { supply and water content at } 4 \\
\text { depths. Simulation modelling } \\
\text { of crop growth and N supply } \\
\text { using (STICS) at this site } \\
\text { ongoing. }\end{array}$ \\
\hline
\end{tabular}

The development methodology is illustrated on Fig. 3. As already said, it is rooted in end-users' needs. Several workshops have been organized to collect the end-users' "wish list" (step 1). This led to sensing requirements for each end-user partner. These requirements, expressed in terms of measurement range and accuracy, are summarized in TABLE II: they are currently used in the development of the different nutrient and gas sensors (step 2). They will be delivered to the integration team to build the SARMENTI device that will be tested in real-life environments.

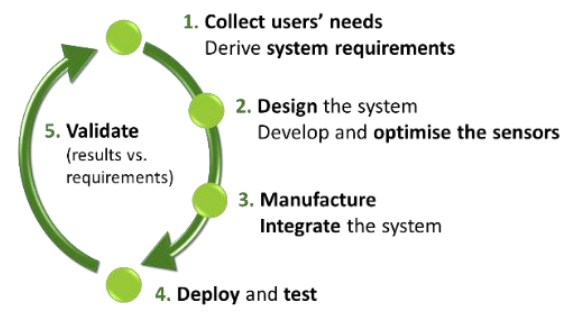

Fig. 3. SARMENTI development methodology 
TABLE II. INFORMATION TO BE SENSED (RANGE, RESOLUTION) BY TEST SITE

\begin{tabular}{|c|c|c|c|c|c|c|}
\hline \multirow{2}{*}{ Information } & \multicolumn{2}{|c|}{ Ireland (Teagasc) } & \multicolumn{2}{|c|}{ Romania (Spiro) } & \multicolumn{2}{|c|}{ France (Terrasolis) } \\
\hline & Range & Resolution & Range & Resolution & Range & Resolution \\
\hline $\mathrm{N}$ (nitrogen) & $0-50 \mathrm{ppm}$ & 0.1 & $\mathrm{X}$ & & $0-50 \mathrm{ppm}$ & 0.1 \\
\hline $\mathrm{P}$ (phosphorous) & $0-2 \mathrm{ppm}$ & 0.1 & $\mathrm{X}$ & & $0-2 \mathrm{ppm}$ & 0.1 \\
\hline K (potassium) & $0-160 \mathrm{ppm}$ & 0.1 & $\mathrm{X}$ & & $\mathrm{X}$ & \\
\hline $\mathrm{pH}$ & $5-10$ & 0.1 & & & $5-9$ & 0.1 \\
\hline Do & $1-10$ & 0.5 & & & & \\
\hline Temperature & $-5 \sim+40{ }^{\circ} \mathrm{C}$ & 0.5 & & & $-5 \sim+40^{\circ} \mathrm{C}$ & 0.5 \\
\hline Relative Humidity & $30 \%$ to $90 \%$ & $5 \%$ & & & & \\
\hline Pressure & $0.9 \sim 1.1 \mathrm{~atm}$ & $0.01 \mathrm{~atm}$ & & & & \\
\hline UV Index & $2-9$ & 0.1 & & & $\mathrm{X}$ & \\
\hline VOC Level & $\mathbf{X}$ & $\mathbf{X}$ & & & $\mathrm{X}$ & \\
\hline $\mathrm{NH}_{3}$ (Ammoniac) & $0-9$ & 0.1 & $\mathrm{X}$ & & $\mathrm{X}$ & \\
\hline $\mathrm{N}_{2} \mathrm{O}$ (Nitrous Oxide) & $0-100$ & 1 & $\mathrm{X}$ & & $\mathrm{X}$ & \\
\hline $\mathrm{CH}_{4}$ (Methane) & $1-1000$ & 1 & $X$ & & $\mathrm{X}$ & \\
\hline
\end{tabular}

\section{SARMENTI is developed in two stages (see Fig. 4):}

the first stage has started in 2019 with the collection of users' needs and requirements. Then, the sensors brought to the project by partners are optimized for the application and, where necessary, new features and functionalities are added. This stage will deliver a first prototype in June 2020 that will be tested in laboratorybased growth chambers to evaluate the device performances and compliance with its requirements;

at the begining of the second stage, the test results will feed back the sensor developments and a second prototype will be delivered in April 2021. Then, SARMENTI end-user partners - located in France, Ireland and Romania - will evaluate the SARMENTI system robustness and reliability at sensing soil nutrient concentrations and gaseous emissions across a range of field sites representative of pedoclimatic conditions and for different crop types in Europe.

\section{SARMENTI DEVICE ARCHITECTURE}

\section{A. Device overview}

The development of the SARMENTI device requires Research and Innovation activities in nano-electronics, electrochemistry, micro-electro-mechanics, biotechnologies, chemistry, data analytics, communication, embedded software, edge computing, and cybersecurity for the IoT. The SARMENTI device consists in fact of three parts, see Fig. 5 for the initial thought:

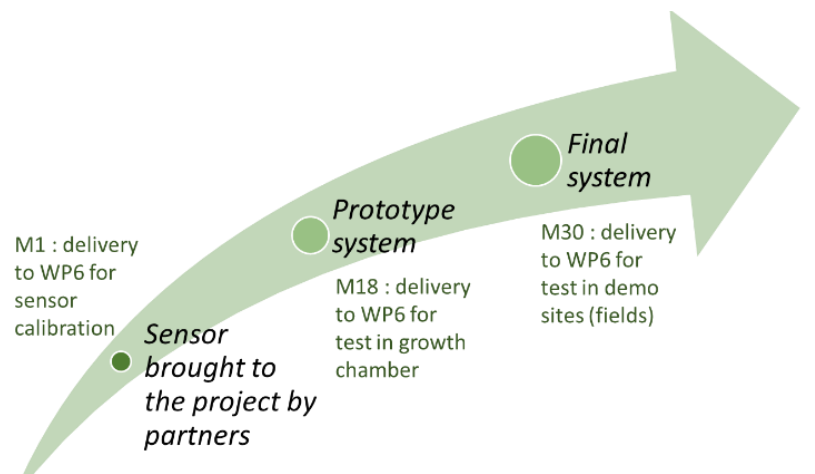

Fig. 4. SARMENTI development stages (i) the Soil Probe, buried in the soil, contains electrochemical sensors. It also measures $\mathrm{pH}$, moisture and ground temperature. The sensors are aggregated in a common multi-parametric miniaturised platform encapsulated in a membrane that will act as a passive microfluidic pump. This latter will be based on superabsorbent polymers coupled to a capillary flow water pump. This aspect constitutes one of the major challenges of the project;

(ii) the Air Probe monitors environmental conditions just above the ground, including temperature, humidity, concentration of Ammonia $\left(\mathrm{NH}_{3}\right)$, Nitrous Oxide $\left(\mathrm{N}_{2} \mathrm{O}\right)$ and Methane $\left(\mathrm{CH}_{4}\right)$;

(iii) the Smart Data Logger collects data from both probes and transmits them directly to the cloud either through a mobile device (via Bluetooth Low Energy - BLE) or a concentrator with LoRA or SigFox connectivity.

Note that the Smart Data Logger provides IoT capability to the SARMENTI device. Back-end servers store the data collected by the node and analyse them with advanced analytics, taking into account weather forecast. The farmer finally receives advices about the best options for fertilizing the crop.

The prototype under development slightly differs from the envisioned one, see Fig. 6. As can be seen, the air probe and the smart data logger are located on the soil surface. The soil probe is buried in the soil at the depth required by the user. A rainwater collector has been added to transmit "clean water" close to the soil probe for cleaning of the sensing platforms and hygroscopic membrane. The interest for such a

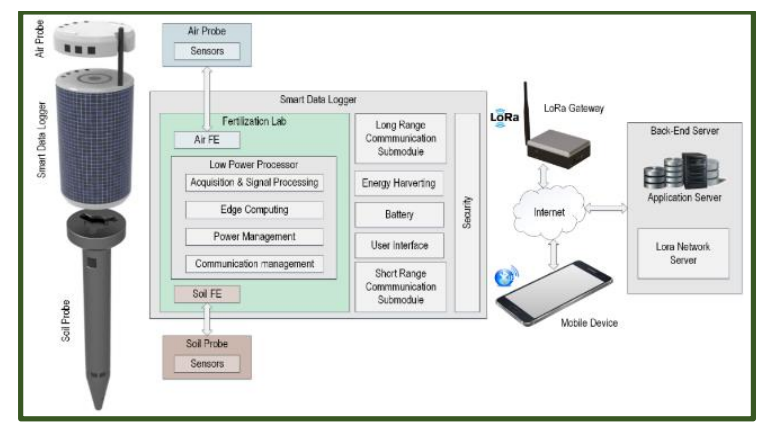

Fig. 5. SARMENTI device architecture (initial thought) 
water reservoir will be evaluated during the tests carried out in growth chambers with the SARMENTI device.

\section{B. Nutrient sensors}

Two complementary set of electrochemical sensors are integrated in the soil probe, namely, nanowire sensors [11][12] and potentiometric sensors [13][14] (more precisely Ion Selective Electrodes (ISE)). The partners brought initial sensing platform prototypes to the project (Fig. 7) that must be optimised to deal with the measurement requirements, and compound under study. Note that to evaluate the different nutrient concentrations, water must be extracted from the soil, hence the membrane in which the sensors are encapsulated. Note that aging and calibration of the sensors over a whole crop lifetime might are also part of the study.

\section{Gas sensors}

The gas sensors integrated in the soil probe are Metal Oxide Sensor (MOS) based on STMicroelectronics MEMS technology. In general, Metal Oxide Semiconductor gas sensors are suitable for many applications in different industries. They are based on a Micro Hot Plate (MHP) continuously heated on time for allowing the sensing material (MOS) to be reactive in presence of Volatile Organic Compounds (VOC). Typically, the VOC concentration is computed as a function of the variation of the MOS Resistance in presence of VOC in clean air. The calibration of the MOS sensing material at specific working conditions enables to translate this ratio into gas concentration ( $\mathrm{ppb}$ or $\mathrm{ppm}$ ). Most of the research activities focus on improving the sensitivity towards the target gases, current driving condition for low power consumption, calibration strategy for Ammonia $\left(\mathrm{NH}_{3}\right)$, Nitrous Oxide $\left(\mathrm{N}_{2} \mathrm{O}\right)$ and Methane $\left(\mathrm{CH}_{4}\right)$, selectivity enhancement for these gases, interfering and poisoning gases. Edge computing is integrated in the soil probe to recognize the presence (and concentration) of gases of interest. Here again, calibration and aging of the sensors is part of the research activity.

\section{SUMmary AND FUtURE WORK DIRECTION}

The objective of the SARMENTI H2020 EU project is to develop an IoT device that monitors in real-time and in situ nutrients in the soil and gaseous emissions just above the soil, and provide advices to the farmer regarding appropriate fertilization strategies.

The first year (2019) of the SARMENTI project has been dedicated to user-needs' collection. These later have been used to derive the device requirements, especially in terms of measurement requirements, as shown in TABLE II. Then the device has been designed, following a modular approach to ease testing and validation, and allow sub-devices to follow their own exploitation routes (i.e. in other application domains).

At the time of writing, the different sensors have been designed and manufactured, and preliminary tests are conducted, with comparison with off-the-self sensors or standard nutrient soil testing methods. Part of these results will be shown during the oral presentation. The sensors will be delivered in June 2019 for integration in the soil and air probes. The Smart Data Logger PCBs have been

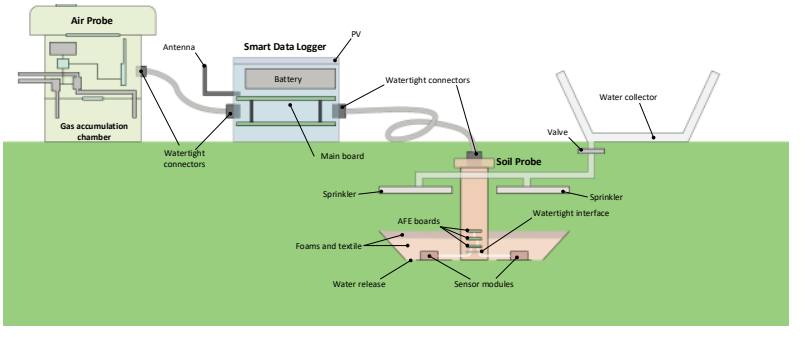

Fig. 6. $1^{\text {st }}$ prototype under development

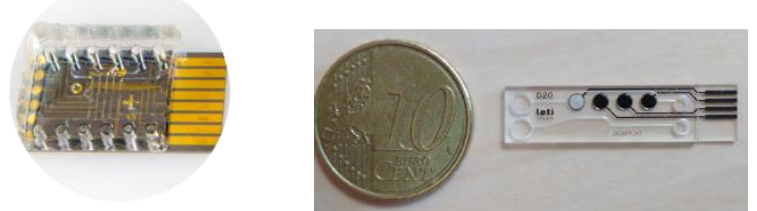

Fig. 7. Nanowire (left) and potentiometric (right) sensors brought to the project by partners

manufactured and assembled and its firmware is under development. The next steps will be to assemble the device prior its evaluation in growth chambers during the second semester of 2020

\section{ACKNOWLEDGMENT}

SARMENTI has received funding from the European Union's Horizon 2020 research and innovation programme under grant agreement No 825325.

\section{REFERENCES}

[1] Food for Life, "Transforming the EU agri-food sector", 2018

[2] D. Zu, et al., "The soil Nutrient monitoring system", Adv. Sc. And Tech Letters, pp. 88-95, 2014.

[3] "Food for life European technology platform", Strategic Research Agenda 2007-2020.

[4] "Land degradation and desertification", study for the European Parliament's Committee on the Environment, Public Health and Food Safety. IP/A/ENVI/ST/2008-23, 2009.

[5] Fact Sheet on "The EU Nitrates directive", 2010, https://eurlex.europa.eu/

[6] "EPoSS Scientific Research Agenda", https://www.smart-systemsintegration.org/public/documents/publications, 2017.

[7] EuroStat, "Agri-environmental indicator - greenhouse gas emissions" http://ec.europa.eu/eurostat/statistics-explained/index.php?title=Agrienvironmental indicator - greenhouse gas emissions, , 2017.

[8] https://iotsecurityfoundation.org/

[9] European Union Agency for Network and Information Security (ENISA), "Baseline Security Recommendations for IoT", https://www.enisa.europa.eu/, 2017.

[10] http://www.physicalgeography.net/fundamentals/9s.html

[11] Alan O'Riordan, K. Dawson, A. Wahl, "Nanowire Electrode Sensors", Patent EP2735868B1 US9671432B2.

[12] Tarasov, Alexey, et. al. "A potentiometric biosensor for rapid on-site disease diagnostics", Biosensors and Bioelectronics, Vol. 79, pp. 669678, 2016.

[13] G. Scheiblin, A. Aliane, X. Strakosas, V. Curto, R. Coppard, G. Marchand, R. Owens, P. Mailley, G. Malliaras, "Screen-printed organic electrochemical transistors for metabolite sensing", MRS Comm., Vol. 5, 2015.

[14] Gaëtan Scheiblin, et al., "Referenceless pH Sensor using Organic Electrochemical Transistors", Adv. Mater. Tech, Vol. 2, 2017. 